\title{
Durûs Al-Lughah Al-‘Arabiygah Karya Mahmud Yunus Dalam Perspektif Nazariyyah Al-Wahdah
}

\author{
Oleh: Yusuf Salam*
}

\begin{abstract}
Durus Al-Lughah Al-Arabiyah (DLA) is one out of 72 works of Mabmud Yunus. This book consists of four series in which the approach of Nazariyyah Al-Wabdah was applied. This approach deals with taking themes or texts as the main or center for learning activities of Arabic: sounds, vocabulary, grammar, literature and media use. These five aspects were used by Mahmud Yunus in DLA. The concurrence of DLA and approach of Nazariyyah Al-Wahdah was achieved by making materials related one another.
\end{abstract}

Kata Kunci: nazariyyah- Al-wahdah

\section{PENDAHULUAN}

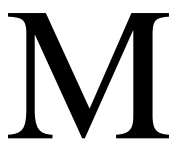

ahmud Yunus salah seorang alumni Timur Tengah. Dalam percaturan pembaharuan pendidikan di Indonesia, dia mempunyai andil dan peran yang sangat besar. Pembaharuan pendidikan Islam oleh Mahmud Yunus dilakukan pada beberapa aspek, di antaranya metode pengajaran, teori pengajaran, dan materi pelajaran, terutama pada pengajaran bahasa Arab (Sonardjo 1977 :40).

Meminjam bahasa Greg Barton, pembaharuan pendidikan ala Mahmud Yunus amat terasa pada pengajaran bahasa Arab. Menurut Mahmud Yunus, sudah saatnya tujuan pengajaran bahasa Arab itu 'naik kelas.' Kalau awalnya hanya untuk menerjemahkan dan memahami teks berbahasa Arab, sekarang tujuan pengajaran bahasa Arab bagaimana siswa mampu mendengar (sima') dan berkomunikasi (muhâdatsah) (Armai Arief: 2002:45)

Untuk mencapai tujuan pembelajaran semacam itu, Mahmud Yunus memanfaatkan waktu libur panjang selama 4 bulan (Mei-Agustus) di Dâr al-'Ulûm untuk berkarya. Waktu liburan inilah Mahmud Yunus berhasil merampungkan sebuah buku pelajaran bahasa Arab untuk orang Indonesia dengan judul "Durûs al-Lughah al"Arabiyyah" (selanjutnya disingkat $D L A)$. Setelah naskah DLA selesai, Mahmud Yunus memperlihatkan naskahnya untuk dikoreksi kepada Syeikh Sastra Arab dan penyair yang termashur pada masa itu, yaitu Muhammad 'Abdul Wahâb. Syeikh Muhammad 'Abdul Wahâb mengoreksi bahasanya. Bukan metodenya dari buku yang terdiri dari dua jilid dengan satu buku pada jilid I dan dua buku jilid II (Mahmud Yunus: 1982)

Setelah melalui proses editing dan koreksi yang dilakukan oleh dosen sastra Arab Dâr al-'Ulûm, buku Mahmud Yunus dinilai layak naik cetak. Dengan merogoh kantong sendiri yang dikirim oleh pamannya di Indonesia pada tiap tiga bulan sekali,

* Penulis adalah Asisten Ahli dalam Mata Kuliah Ilmu Sharaf Pada STAIN Batusangkar 
Mahmud Yunus mencetak buku itu sebanyak 10.000 eksemplar. Buku tersebut dikirim ke Malaysia dan Indonesia.

DLA ditulis alumni Dâr al- 'Ulûm tersebut, dilatarbelakangi oleh gagasannya untuk menyesuaikan materi pelajaran bahasa Arab dengan alam Indonesia supaya dapat menarik perhatian siswa. Di sisi lain, Mahmud Yunus menyatakan bahwa pengajaran bahasa Arab yang berlaku selama ini juga bertolak dari anggapan bahwa mata pelajaran bahasa Arab yang ada merupakan satuan yang terpisah satu sama lain. Maka dalam pelaksanaannya, pelajaran al-sarf, al-nahwwu, al-muhâdatsah, mutâla'ah dan al-insyâ' disampaikan secara terpisah. Ia mengusulkan agar cara pandang seperti itu diubah dengan pandangan melihat kesemua materi tersebut sebagai kesatuan yang tak terpisahkan (Didin Syafruddin, 1995 : 176).

Atas dasar itu, penulis mencoba menganalisa salah satu aspek yang terkait dalam pembelajaran bahasa Arab. Aspek yang dimaksud adalah materi pembelajaran bahasa Arab, karena materi merupakan aspek yang sama pentingnya dengan aspek lain, seperti metode, guru, dan siswa.

Adapun materi yang penulis maksud dalam pembahasan ini, yaitu materi buku DLA. Sebagaimana diketahui bahwa tujuan utama pembelajaran bahasa Arab dengan menggunakan buku ini adalah untuk mendapatkan keterampilan berbahasa (menyimak, berbicara, membaca, dan menulis) dan unsur-unsur bahasa (bentuk kata, struktur kalimat, kosakata) secara utuh tanpa dikotak-kotakkan.

\section{TINJAUAN TENTANG NAZZARI- YYAH AL-WA}

\section{Pengertian Teori Kesatuan (Nazari- yyah al-Wahdah)}

Nazariyyah al-Wahdah terdiri dari dua kata dalam bentuk idâfah Nazariyyah dan al-Wahdah. Kata Nazariyyah (theory dalam bahasa Inggrisnya dan teori dalam bahasa Indonesianya) adalah kata yang mempertalikan dua istilah yang berbeda, Nazariyyah al-Wahdah dan Nazariyyah al-Furû'i. Secara etimologi Nazariyyah bermakna "asas dan hukum yang menjadi dasar suatu keahlian (art, seni) atau ilmu pengetahuan". Penggunaan kata itu seperti: مفهوم "pergertian nahwu menurut teori baru" (Moh. Mansur: 1985: 63).

Abdul Alîm Ibrâhîm menjelaskan bahwa teori kesatuan (Nazariyyah alWahdah) adalah suatu sistem atau teori yang memandang bahasa sebagai satu kesatuan yang saling terkait dan tidak dibagi kepada cabang-cabang terpisah. (Abdul Alîm Ibrâhîm, 1968:51) Sedangkan menurut Moh. Mansyur, yang dimaksud dengan teori kesatuan (Nazariyyah al-Wahdah) adalah mengajarkan bahasa Arab dengan melihatnya sebagai satu kesatuan yang utuh, tidak terpecahpecah menjadi beberapa cabang. (Moh. Mansur 1985: 63).

Sementara itu, teori kesatuan (Nazariyyah al-Wahdah) yang dalam istilah Mahmûd Ibrâhîm Shînî, dkk., disebut tarîqah al-mutakâmilah adalah suatu pendekatan yang melihat bahasa sebagai satu kesatuan yang utuh dan saling melengkapi (Mahmûd Ibrâhim Shînî, Al-'Arabiyah, 1983: f). Mahmûd Ibrâhîm Shînî, dkk, menerapkan teori kesatuan pada bukunya al-'Arabiyyah Li-al-Nâsyi'în yang terdiri dari 6 jilid. Pendekatan yang diterapkan Mahmûd Ibrâhîm Shînî, dkk, pada buku al'Arabiyyah Li-al-Nâsyi'în ini memberi- 
kan perhatian terhadap keterampilan bahasa secara seimbang, yaitu keterampilan mendengar, (mahârah alistimấ), keterampilan berbicara (mahârah al-kalâm), keterampilan membaca (mahârah al-qirâ'ah), dan keterampilan menulis (mahârah al-kitâbah). Selain itu, pendekatan ini juga memberikan perhatian terhadap berbagai unsur bahasa Arab, seperti bunyi huruf (ashwât), kosa kata (mufradât), tata bahasa (qawâ'id), intonasi (nabr) dan lagu (tanghîm).

Teori kesatuan (Nazariyyah alWahdah) disebut juga Integratif adalah ancangan (kebijakan) pembelajaran bahasa dengan menyajikan bahan ajar secara terpadu, yaitu dengan menyatukan, menghubungkan, atau mengaitkan bahan ajar sehingga tidak ada yang berdiri sendiri atau terpisah-pisah (Subana dan Sunarti, tt: 70). M. Zaini Dahlan menyatakan bahwa teori kesatuan (Nazariyyah al-Wahdah) lebih menekankan kemampuan berbahasa lisan, yang kemudian diiringi pembinaan dalam pembendaharaan kata, gramatika (ilmu tata bahasa) dan ilmu sastra (keindahan bahasa). Menurutnya, penyajian pelajaran bahasa dengan teori kesatuan (Nazariyyah al-Wahdah) ini selalu mengunakan sistem gambar dalam beberapa peta. Tiap-tiap gambar dalam peta akan berulang-ulang dipergunakan dalam berbagai kalimat percakapan, yang tujuannya dapat memudahkan para siswa untuk menghafal tanpa sengaja dan lancar dalam berbahasa secara otomatis. Keutamaan sistem ini dapat digunakan baik di sekolah, kursus, maupun belajar sendiri (Zaini Dahlan, 1975:6).

Dari berbagai pendapat di atas, terdapat beberapa perbedaan istilah tentang Nazariyyah al-Wahdah, meskipun pada hakikatnya ada kesamaan pandangan bahwa keterampilan berbahasa dan unsur bahasa disajikan secara terpadu (terintegrasi). Bahasa dipandang sebagai suatu kesatuan yang utuh, saling berhubungan dan berkaitan; bukan sebagai bagian-bagian yang terpisah satu sama lain. Oleh karena itu, semua aspek pengajaran bahasa diajarkan pada waktu yang bersamaan dan tidak dipisahkan antara satu aspek dan aspek lainnya.

Dari pendapat-pendapat di atas, defenisi secara lengkap agaknya diberikan oleh Abdul Alîm Ibrâhîm, menjelaskan bahwa teori kesatuan (Nazariyyah al-Wahdah) adalah teori yang memandang bahasa sebagai satu kesatuan yang utuh dan saling melengkapi. Dalam menerapkan teori ini suatu tema atau teks dijadikan sebagai induk atau sentral kegiatan pembelajaran bagi berbagai cabang bahasa Arab. Teks itulah sebagai bahan bacaan, mengungkapkan, merasakan, menghafal, dikte, latihan bahasa dan lain-lain. Oleh karena itu, hanya ada satu mata pelajaran, satu kali pertemuan, satu buku, satu evaluasi, dan satu nilai hasil belajar.

Berdasarkan terminologi di atas, dapat dipahami bahwa teori kesatuan (Nazzariyyah al-Wahdah), menekankan kesatuan, yang disatukan adalah unsur bahasa Arab yang meliputi bunyi huruf (aswât), kosa kata (mufradât), tata bahasa (qawâ'id), sastra, keterampilan berbahasa secara lengkap yang meliputi keterampilan mendengar, berbicara, membaca, dan menulis, dan penggunaan media gambar sebagai upaya memudahkan siswa dalam memahami sebuah bahasa. Dalam pelaksanaan teori ini adalah penyajian materi dalam satu paket pengajaran, satu kali pertemuan, satu buku, satu evaluasi, dan satu nilai hasil belajar. Oleh sebab itu, penyajian pengajaran bahasa Arab dengan teori kesatuan (Nazariyyah al-Wahdah) merupakan sarana mewujudkan bahasa yang komunikatif; aktif dan fasif. 
Menurut Ali Muhammad AlQâsimî buku pelajaran yang baik untuk mengajarkan bahasa Arab kepada orang bukan Arab, ialah buku yang menyajikan bahasa Arab sebagai bahasa dan isi, sebagai ucapan dan tulisan (Ali Muhammad Al-Qâsimî, 1979: 119-120) Dalam bukunya العريية المعاصرة للناطقين (Bahasa Arab Bagi Orang Berbahasa Perancis) Al- Qâsimî menyajikan urutan pelajaran sebagai berikut:

a. Bicara ( ), Bicara untuk menciptakan situasi hidup dalam bentuk percakapan,

b. Membaca, ( ) Membaca untuk mengembangkan bacaan percakapan tersebut,

c. Bicara ( ) Bicara berupa latihan lisan menggunakan struktur dan kata-kata percakapan,

d. Menulis ( ) Menulis jawaban latihan-latihan itu secara tertulis di dalam kelas atau di rumah,

e. Membaca( ) Membaca berupa potongan pendek untuk dibaca dan dipahami,

f Menulis ( ) Menulis berupa mendiktekan potongan itu atau potongan lain, dan

g Bicara ( ) membedakan satuansatuan bunyi Arab yang sukar dan mengucapkannya dalam kata atau kalimat.

Skenario di atas mengambarkan hubungan antar materi saling koordinatif dan tidak terkotak-kotak kepada materi yang berdiri sendiri. Model penyajian materi di atas adalah satu teks pelajaran disajikan empat keterampilan berbahasa secara terpadu dan saling terkait.

\section{Kekuatan Nazariyyah al-Wahdah}

Kelebihan teori ini adalah dasardasar teoritisnya yang kuat, baik dasardasar kejiwaan, dasar-dasar pendidikan maupun dasar kebahasaan.

\section{Dasar-dasar Teori Ilmu Jiwa (Psiko- logi)}

a. Teori kesatuan membangkitkan semangat dan menghilangkan kejenuhan, karena banyak cabang bahasa yang dipelajari dan bervariasinya bidang kegiatan. Kegiatan belajar diadakan bervariasi dari berbicara atau membaca, lalu menganalisa makna mufradât, dan pindah lagi ke analisa qawâ‘id dan seterusnya.

b. Siswa mantap dan bertambah jelas memahami masalah, karena dalam teori ini siswa mengulang-ulang pelajaran, dalam satu tema, tetapi dalam sub-sub tema yang berlain-lain. Mengulang-ulang pelajaran itu menambah lekat dalam otak dan menambah pengertian.

c. Teori kesatuan dilaksanakan dengan cara memahami sesuatu secara global lebih dahulu, kemudian mendetail kepada bagian-bagian. Ini seiring dengan watak anak.

Bila dikaitkan dengan teori psikologi, maka teori kesatuan sesuai dengan teori Gestalt. Menurut psikologi Gestalt, bahwa dalam pengamatan, pikiran tidaklah membentuk pengamatan keseluruhan dari bagian-bagian kecil benda yang diamati itu, tetapi terlebih dahulu melihat benda itu secara keseluruhan barulah kemudian bagianbagian kecilnya (Lihat Abdul Chair, Psikolinguistik Kajian Teoritik, (Jakarta: Rineka Cipta, 2003, 98).

Sistem terpadu ini sesuai dengan tabiat atau cara kerja otak dalam memandang sesuatu, yaitu dari global ke bagian-bagian. Variasi bahan dan variasi penyajiannya menghindarkan siswa dari kejenuhan. Fokus kepada satu topik atau satu situasi, tetapi dengan peninjauan berulang-ulang dari berbagai segi, memperkuat pemahaman siswa terhadap materi pelajaran. 
Dasar-Dasar Teori Kependidikan (Didaktik)

a. Teori kesatuan menjalin hubungan yang erat antara aneka ragam pelajaran bahasa (bercakap-cakap, membaca, nahwu/sharf, dll).

b. Teori kesatuan menjamin pertumbuhan bahasa secara serasi dan seimbang antara berbagai cabang keterampilan siswa, karena tidak diutamakan satu dari yang lain.

Dari segi kependidikan ini, jelaslah bahwa sistem terpadu menjamin terwujudnya pertumbuhan kemampuan berbahasa secara seimbang, karena semuanya ditangani dalam situasi dan kondisi yang sama, tidak dipengaruhi oleh keberagaman semangat dan kemampuan pengajar.

\section{Dasar-Dasar Teori Kebahasaan}

Dipandang dari sudut kebahasaan, sistem terpadu sejalan dengan tabiat bahasa sebagai sebuah sistem, dan sesuai dengan realita penggunaan bahasa yang memadukan berbagai unsur bahasa dan keterampilan berbahasa secara utuh.

\section{Kelemahan Nazariyyah al-Wahdah}

Kelemahan Nazariyyah al-Wahdah, muncul atau tampak ketika diterapkan pada siswa tingkat lanjut yang telah mempelajari bahasa Arab dasar Di sini Nazariyyah al-Wahldah kurang memenuhi kebutuhan siswa yang ingin mendalami unsur bahasa atau keterampilan berbahasa tertentu yang memang menjadi kebutuhan nyata daripada pembelajar.

Berdasarkan ini, pengembangan pengajaran bahasa Arab dengan pendekatan teori kesatuan cocok untuk siswa pemula atau program pengajaran bahasa Arab dengan sistem madrasah (Ibtidaiyah, Tsanawiyah, dan Aliyah, serta Perguruan Tinggi Agama Islam yang jurusannya bukan bahasa/sastra Arab).

\section{Variasi Bahan Utama Pada Nazari- yyah al-Wahdah}

Buku teks bahasa Arab sebagai salah satu sumber belajar dan pemandu kegiatan siswa, memiliki bahan utama yang beragam. Bahan utama yang dijadikan basis pembelajaran dalam buku tentang ini terdapat dua bentuk, yaitu: pembelajaran berbasis topik atau teks bacaan, dan pembelajaran berbasis situasi atau teks percakapan.

\section{Pembelajaran berbasis Topik atau Teks Bacaan}

Bahan pelajaran utama di sini berupa bacaan mengenai topik tertentu. Dari bahan utama ini dapat dikembangkan berbagai kegiatan pembelajaran, antara lain;

a. pemahaman kosa kata,

b. pemahaman dan analisa isi teks,

c. penguasaan bunyi-bunyi bahasa melalui kegiatan membaca keras,

d. percakapan dengan topik yang relevan,

e. latihan menulis berdasarkan isi bacaan,

f. pemahaman teks simakan yang paralel dengan teks bacaan, dan

g. penguasaan struktur atau tata bahasa yang terdapat dalam teks.

Bentuk variasi bahan utama di atas yang berfokus kepada materi bacaan akan dikembangkan dalam bentuk kosakata, percakapan, struktur kalimat, dan menulis. Fokus utama dapat dilakukan dengan menghubungkan atau mengaitkannya dengan pembelajaran yang setelahnya secara terpadu dan saling koordinatif antar materi. 


\section{Pembelajaran Berbasis Situasi atau Teks Percakapan}

Bahan pelajaran utama di sini berupa teks percakapan dalam situasi tertentu atau mengenai topik tertentu. Dari bahan utama ini dikembangkan berbagai kegiatan antara lain;

a. dramatisasi teks sampai dengan percakapan bebas,

b. latihan melafalkan dan membedakan bunyi-bunyi tertentu,

c. latihan menulis dengan mengubah teks dialog menjadi narasi,

d. memahami teks bacaan atau simakan yang paralel, dan

e. pembahasan struktur atau tata bahasa tertentu yang ada dalam teks.

Sistematika dari susunan materi pelajaran bahasa yang berpusat kepada teks percakapan di atas adalah (a) teks percakapan dan latihannya, (b) teks bacaan, dan (c) struktur atau tata bahasa.

\section{Prinsip-Prinsip Pengajaran Bahasa Asing Dalam Perspektif Nazariyyah al-Wahdah}

Dalam pengajaran bahasa Arab yang notabene menggunakan Nazariyyah al-Wahdah harus memperhatikan prinsip-prinsip pengajaran bahasa asing. Prinsip-prinsip yang menjadikan kajian disini di antaranya adalah Gradasi (tahapan), yakni tingkatan yang harus dilalui dalam proses pembelajaran bahasa. Pentahapan pengajaran merupakan prinsip pendidikan yang mesti diaplikasikan dalam berbagai situasi belajar, baik untuk materi pelajaran bahasa maupun untuk pelajaran lainnya. Prinsip pentahapan (gradasi) dalam pengajaran bahasa dapat dikenal dengan lima tahapan berikut ini:

1. Dari tahap yang mudah kepada yang sulit,
2. Dari tahap sederhana kepada yang kompleks,

3. Dari tahap jelas kepada yang samar,

4. Dari tahap konkret kepada yang abtraks, dan

5. Dari tahap yang sering dipergunakan kepada yang jarang dipergunakan. (Kamâl Badri Ibrâhîm, 1986: 4-19).

Gradasi merupakan salah satu asas keberhasilan suatu pengajaran. Prinsip ini menjadikan materi dapat diterima siswa dengan mudah. Rasa mudah menimbulkan semangat. Semangat membawa kerajinan dan pada gilirannya dapat menghasilkan keberhasilan dalam pembelajaran. Sebagaimana rangkaian berikut: o $\rightarrow$ mudah $\rightarrow$ semangat $\rightarrow$ rajin $\rightarrow$ berhasil.

Dengan memahami kelima tahapan pembelajaran bahasa di atas, seorang guru dapat mensosialisakan metodologi pengajarannya sesuai dengan kapasitas kemampuan peserta didik. Loncatan pembelajaran tentunya tidak akan terjadi bila seorang guru telah mengimplementasikan prinsip ketiga ini, karena prinsip gradasi ini setidaknya dapat mengikis munculnya distorsi pemahaman di kalangan siswa. Dengan pemahaman yang sistematis, siswa digiring untuk dapat berfikir logis, sistematis, dan terarah untuk memperoleh sesuatu pengetahuan berbahasa yang komprehensif dan terpadu.

\section{METODOLOGI PENELITIAN}

Fokus utama penelitian adalah pemikiran dalam sebuah teks, sehingga penelitian ini adalah jenis penelitian kepustakaan (Library Research). Penelitian ini dalam mengumpulkan datanya menggunakan teknik pengumpulan data dokumentasi, yaitu pengumpulan data penelitian yang dilakukan dengan cara mengumpulkan sumber-sumber tertulis yang berupa dokumen dalam bentuk buku-buku dan dalam bentuk yang lain. 
Sehubungan dengan objek permasalahan penelitian, maka penelitian ini bertujuan untuk menemukan ide-ide dan pemikiran Mahmud Yunus tentang teori kesatuan yang diaplikasikannya dalam materi pengajaran bahasa Arab buku Durûs al-Lughah al-'Arabiyah. Adanya penemuan tentang ide-ide dan pemikiran Mahmud Yunus tentang teori kesatuan diharapkan mendapat sesuatu yang bermanfaat dalam pengajaran bahasa Arab sekarang.

Penelitian ini, menggunakan dua metode deskriptif analisis dan komparatif. Pertama, analisis deskriptif, yaitu bahwa semua pemikiran Mahmud Yunus yang terkait dengan Nazariyyah al-Wahdah dalam buku DLA akan diuraikan kembali secara utuh berdasarkan tema-tema yang disusun oleh peneliti sesuai dengan tema-tema teori kesatuan yang biasa digunakan dalam rangka untuk memahami jalan pikiran dan maksud yang termuat dalam pemikirannya secara utuh. Analisa data dalam buku ini, dianalisa dari aspek keterpaduan bahan utama dengan sub pokok bahasan yang terdiri dari keterampilam bahasa dan unsur-unsur bahasa.

Kedua, analisis komparatif, di mana dalam menjelaskan masalah penulis tidak hanya mengungkapkan satu pendapat, tetapi juga pendapat lain baik bersifat pro dan maupun kontra dalam mencari alternatif materi yang baik untuk non Arab.

\section{ANALISIS HASIL PENELITIAN}

\section{Urutan Materi Durûs al-Lughah al- 'Arabiysah}

Urutan materi mengambarkan tipe atau silabus yang digunakan dalam pembelajaran bahasa. Pemilihan dan pengurutan materi pelajaran yang akan diberikan kepada siswa amat me- nentukan keberhasilan pencapaian tujuan pembelajaran yang telah ditetapkan. Kesalahan pemilihan dan pengurutan materi pelajaran dapat berakibat pada kegagalan terhadap pencapaian tujuan tersebut. Oleh sebab itu, materi pelajaran hendaknya disusun sesuai dengan ruang lingkup dan dengan urutan yang jelas. Karena materi sebelumnya dapat menjadi pra-syarat bagi materi atau bahan pelajaran sesudahnya. Adapun penyajian materi dalam $D L A$ mengambil format sebagai berikut:

\section{Kosakata (mufradât)}

Kosakata merupakan salah satu unsur terpenting sebuah bahasa. Ia berfungsi sebagai pembentuk ungkapan, kalimat, dan wacana. Sedemikian pentingnya kosakata, sehinga ada yang berpendapat bahwa pembelajaran bahasa asing harus dimulai dengannya, baik dengan cara menghapalkan dan maupun dengan cara yang lain(Mamdûh Nuruddin: 1407. 1).

Kosakata dalam DLA disajikan pada urutan pertama. Kosakata tersebut merupakan kosakata kunci dari setiap topik atau tema yang disajikan. Fungsinya adalah untuk membantu guru dalam mempertimbangkan bahan ajar yang akan dikembangkan untuk tema tertentu sesuai dengan tingkat perkembangan siswa. Menurut hemat penulis, teknik penyajian tersebut dapat pula membantu siswa dalam mempelajari bahasa Arab serta menumbuhkan motivasi mereka belajar mandiri. Karena sebelum siswa belajar berbicara dan membaca didahulukan dengan pengenalan kosakata.

Kosakata yang disajikan Mahmud Yunus pada setiap dars antara 8-28 kosakata baru. Jumlah kosakata tersebut adalah sesuai dengan usia anak sekolah tingkat Tsanawiyah dan Aliyah. Hal ini sejalan dengan hasil penelitian Thu'aimah, bahwa anak di atas usia 10-11 bisa menyerap 8-30 kosakata baru. Usia 
tersebut adalah usia siswa tingkat Tsanawiyyah dan Aliyah (Firdaus: 2006:83)

\section{Bacaan (Mutâla'ah)}

Urutan kedua adalah mutâla'ah merupakan poros utama pembahasan. Sebab materi percakapan dan penerapan tata bahasa dibangun di atas poros utama tersebut. Secara nominal, setiap pelajaran (dars) terdiri atas 95 (sembilan lima) pelajaran meliputi kosa kata, mutâla'ah, muhâdatsah, tata bahasa dan latihan.

Menurut Mahmud Yunus, materi mutâla' ah merupakan materi dasar yang dapat dikembangkan menjadi materi percakapan, melatih kemampuan pendengaran dan kemampuan memahami. Bahkan dari pola-pola kalimat dan pemakainnya dapat dikembangkan pula menjadi pelajaran tata bahasa.

Mutâla'ah tersebut merupakan gambaran dari tema yang disajikan pada setiap dars. Tema-tema tersebut senantiasa dikaitkan dengan kehidupan dan lingkungan siswa di mana dia hidup. Suatu hal yang sia-sia menyajikan bacaan yang jauh dari lingkungan siswa, terutama siswa pemula (mubtadiîn). Seperti wacana tentang keadaan geografis Arab Saudi, dan atau bendabenda yang ada di sana.

\section{Percakapan (Muhâadatsah)}

Pernyataan verbal antara dua pihak tentang tema tertentu dinamakan muhâdatsah(percakapan). Bentuk percakapan dalam DLA mengambil bentuk dialogis (al-as'ilah wa al-ajwibah). Sementara materi percakapannya merupakan pengembagan atas struktur kalimat berita pada materi mutâla'ah. Cara pengurutan Mahmud Yunus di atas (dari mutâla'ah kemudian muhâdatsah) adalah sejalan dengan apa yang dikemukakan Kamâl Badri Ibrâhîm (Kamâl Badri Ibrâhîm, 1407 :12). Dengan demikian teori Mahmud Yunus sejalan dengan teori modern. Sebab diakui materi percakapan dengan menggunakan kalimat pertanyaan lebih sulit dibandingkan kalimat berita. Karena hal ini menuntut pemahaman siswa terhadap adawât istifhâm yang mendahuluinya.

Adawât istifhâm adalah kata-kata operasional yang lazim digunakan dalam bertanya. Diantaranya hal (apakah), hamzah (apa), kaifa (bagaimana), ma (apa), aina (dimana), man (siapa), kam (berapa) dan lain-lain. Buku DLA menggunakan kata bantu di atas dalam muhâdatsah sebagai keniscayaan. Yang patut diperhatikan adalah pilihan atas penggunaan kata bantu tersebut. Misalnya dalam $D L A$ jilid 1, pada pelajaran pertama. Apa yang digunakan adalah hanya dua kata yang diperkenalkan yaitu mâ (apa) hamzah (apakah).

Sementara dilihat dari teori Taksonomi Bloom (Bloom's Taxonomy of Classroom Questions) maka kedua buku tersebut adalah sama. Dalam teori ini dijelaskan tingkat-tingkat kognisi dari bentuk kata bantu (adâwât istifhâm), yaitu mulai dari pengetahuan, pemahaman, aplikasi, analisis, sintesis, hingga evaluasi. Kata Bantu yang disunakan pada tingkat pertama adalah sن . ما , أين, منى , ما

Agaknya teori Taksonomi Bloom digunakan secara konsisten dalam DLA meskipun hanya tiga tingkatan: pengetahuan, pemahaman dan aplikasi.( Fuad effendi, 2005: 132-133). DLA jilid 1 menggunakan adawât istifhâm: ham-

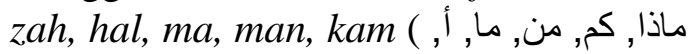
ه). Sementara DLA jilid 2 meng-

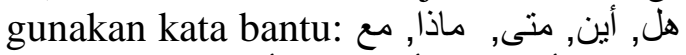

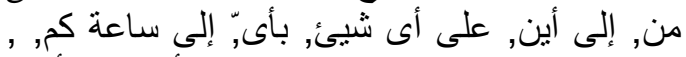
Dengan demikian kata bantu yang digunakan $D L A$ jilid 1 dan 2 berada pada tingkat kognitif pengetahuan. Tingkat kognitif pemahaman berada pada DLA jilid 3, dengan 
menggunakan kata bantu limadza (لماذا), kecuali bagian akhirnya yaitu pada pelajaran ke-42. Pada pelajaran ke-42 ini sudah meningkat kognitifnya pada aspek aplikatif. Karena kata Bantu yang digunakan adalah kaifa (كيف). Sedangkan dalam $D L A$ jilid 4 keseluruhan kata bantu digunakan secara variatif.

\section{Tała Bahasa (Qamâ'id)}

Adapun tata bahasa dalam DLA diberikan setelah materi bacaan dan percakapan. Dengan ungkapan lain, tata bahasa berada pada urutan keempat sesudah mufradât, Mutâla'ah dan muhâdatsah; dan atau sebelum tamrîn. Dilihat dari aspek aplikasi, penyajian tata bahasa dalam $D L A$ jilid 1 dan 2 masih bersifat terapan dan sederhana. Sementara dalam DLA jilid 3 dan 4, selain bersifat terapan namun sudah meningkat pada aspek 'I'rab. Penyajian tata bahasa secara sederhana dan terapan di atas diberikan dengan dibarengkan dalam pelajaran membaca, percakapan dan hafalan untuk tingkat pemula (tingkat pertama). Dengan ungkapan lain, penyajian tata bahasa lebih bersifat sekunder.

Keempat aspek materi (kosakata, bacaan, percakapan, dan tata bahasa) dalam $D L A$ di atas adalah satu kesatuan. Ia tidak berdiri sendiri, meskipun penyajiannya dibagi atas sub-sub bab mata pelajaran tertentu. Penyajian demikian dimaksudkan agar siswa lebih mudah mempelajarinya. Misalnya, pengajaran pola kalimat bahasa Arab fi'il dan fa'il dalam contoh يكتب محمّد الرسالة. Pola ini bersifat gramatikal. Namun dapat pula diajarkan kepada siswa dalam bentuk muhâdatsah. Maka bentuknya menjadi: man yaktub al-risalah/ يكتب الرسالة atau ma yaktub Muhammad dan يكتب

- Dapat menjadi obyek latihan siswa dalam hal kitabah, yaitu dengan menuliskannya secara benar.
Variasi atas keempat aspek tersebut dalam pelajaran bahasa Arab dinilai positif oleh Mahmud Yunus. Karena adanya pengulangan, dan itu memperkuat dan menambah pengertian serta daya ingat siswa atas pelajaran tersebut. Dengan kata lain, pelajaran yang diulang-ulang akan semakin kuat tersimpan dalam memori siswa. Terlebih satu materi dapat diajarkan dalam berbagai bentuk.

Demikian pula dalam hal tema. Mahmud Yunus mengemukanya, menurut teori ini diambil satu tema sebagai pusat, lalu dijadikan bacaan, percakapan, nahwu/sarf dan sebagainya. (Mahmud Yunus, 1980 :26). Dengan demikian tidak ada jam khusus membaca, bercakap-cakap, nahww dan sarf dan sebagainya. Bahwa penyajiaan keempat aspek tersebut harus merujuk kepada tema. Jika tema sentralnya adalah al-sinâ'ah al-wataniyah (perusahaan nasional) misalnya, maka kosakata yang dipakai dalam materi bacaan dan percakapan diambilkan dari pokok sentralnya. Cara seperti ini dilakukan Mahmud Yunus dalam DLA.

Dilihat dari sisi tipologi pengajaran bahasa, kesatuan tema dalam DLA menggunakan pendekatan analitik. Yaitu sebuah pendekatan yang tidak melabeli unit-unit pelajaran atas dasar butir-butir tata bahasa. Akan tetapi berdasarkan perilaku atau situasi. Karena itu, penyajian antara satu materi dengan yang lain tidak terpisahkan.( Fuad Effendi, Pendekatan : 60). Pendekatan ini tentu berbeda dengan silabus struktural (al-Manhaj al-Nahwî) yang menata muatan materi bahasa berdasarkan topik-topik bahasan dalam ilmu nahwu, sehingga unsur-unsur bahasa (mufradât, $n a \underline{h} w u$, dan sarf) diajarkan secara terpisah-pisah. 


\section{Langkah-langkah Penyajian Materi}

Dalam bukunya Metodik Khusus Bahasa Arab, Mahmud Yunus memberikan petunjuk teknis tentang bagaimana mengajarkan bahasa Arab dalam DLAnya. Bahwa pengajaran tersebut menempuh langkah-langkah berikut:

1. Pendahuluan. Pendahaluan dimaksudkan untuk menarik perhatian siswa-siswa untuk belajar bahasa Arab.

2. Guru menyuruh dua orang siswa (putra-putri) ke depan kelas, lalu mengucapkan sambil menunjuk kepada siswa: هذا محمّد (kata diganti dengan nama siswa yang sebenarnya). Kemudian menunjuk kepada seorang siswi, lalu mengucapkan: هذه

(kata diganti dengan nama siswi yang sebenarnya).

3. Guru menyuruh siswa-siswa menyebut dan mencontoh ucapan guru itu:

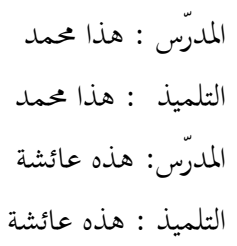

Kalimat tersebut diulang beberapa kali (ini merupakan materi mutâla'ah).

4. Guru menuliskannya di papan tulis dan menyuruh siswa-siswa membacanya secara bergantian.

5. Guru bertanya kepada seluruh siswa sambil menunjuk kepada siswa putra: من هذا ؟

6. Seluruh siswa menjawab: هذا محمّد

7. Guru bertanya lagi sambil menunjuk kepada siswi putri: من هذه

8. Seluruh siswa menjawab: هذه عذائشة . Soal jawab ini dilakukan beberapa kali.

9. Seluruh siswa disuruh bersoal jawab sesamanya; seorang bertanya dan seorang menjawab (ini merupakan pelajaran muhâdatsah).

10. Guru menerangkan (mengambil kesimpulan bersama seluruh siswa), bahwa هذا- ذلك: dipergunakan untuk

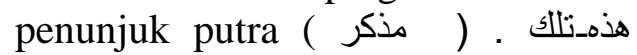
untuk menunjuk putrid (مؤنث) atau kata-kata yang akhirnya : (tâ' marbûtah) nama اسم الإشارة lalu ditulis di

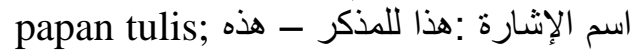
. Faktor utama keberhasilan langkah ini adalah kebijaksanaan para guru dalam memberikan bimbingan dan petunjuk. Oleh sebab itu, guru lebih proaktif mendorong siswa untuk menyimpulkan dan menemukan kaidah sendiri tentang struktur kalimat yang dimaksudkan dalam bahan pelajaran.

11. Diadakan latihan mengisi titik-titik untuk menyempurnakan kalimat, seperti:

$$
\text { (1) (1) هذه.... (3) (4) (4) }
$$

Penyajian materi di atas diawali dengan mendemonstrasikan kosakata, struktur kalimat, dan kalimat dalam materi bacaan secara lisan, mengucapkan suatu kata dengan menunjuk benda atau gambar benda, dan memperagakan sebuah gerakan atau mimik wajah. Siswa menirukan berkali-kali sampai benar pelafalannya dan maknanya dalam bentuk gerakan dengan bahasa.

Langkah-langkah penyajian di atas adalah model teknik penyajian unsur bahasa dan keterampilan berbahasa. Penyajian tersebut dimulai dari menyimak sampai berbicara. Selanjutnya diakhiri dengan menulis dan latihan. Keempat unsur ini adalah satu kesatuan yang tidak terpisahkan

Pertama, siswa mendengarkan suatu kata atau kalimat yang kadangkadang disertai alat peraga visual untuk menjelaskan artinya. Apa yang didengar, kemudian siswa menirukannya. Setelah siswa melafalkannya secara benar, dilanjutkan dengan qira'ah (membaca). Dengan demikian, melafalkan dan membaca adalah langkah kedua dan 
ketiga. Sesudah itu dilanjutkan dengan langkah keempat yaitu menulis.

Sebelum sampai pada langkah membaca, buku dalam keadaan tertutup. Siswa tidak boleh membukanya. Hal ini dimaksudkan agar siswa terkonsentrasi pada apa yang didengarkannya untuk mengucapkannya secara benar. Setelah guru yakin atas kebenaran ucapan siswa, maka dilanjutkan dengan membaca. Dalam tahap ini, buku sudah dapat dibuka oleh siswa.

Petunjuk teknis Mahmud Yunus dalam pengajaran bahasa Arab di atas, menegaskan bahwa keterampilan berbahasa dimulai dengan cara menyimak, berbicara, membaca, dan menulis. Urutan keterampilan ini bukan didasarkan atas urutan materi yang disajikan. Akan tetapi didasarkan atas teknik dan langkah-langkah metodik.

Secara gradual, teknis penyajian tersebut menggambarkan bahwa menyimak adalah keterampilan awal sebelum keterampilan lainnya. Hal ini sejalan dengan perkembangan psikologi anak. Bahwa sebelum anak dapat berbicara dengan baik, ia terlebih dahulu mendengarkan apa yang diucapkan orang sekitarnya. Mendahulukan keterampilan bukan berarti menapikan keterampilan lainnya: mengucapkan, membaca dan menulis. Akan tetapi secara metodik ketiga keterampilan yang disebut terakhir harus didahului oleh keterampilan menyimak.

Teknis dan langkah-langkah di atas berkenaan dengan cara mengajarkan bahasa Arab secara totalitas. Yang terdiri atas empat keterampilan: mendengar-menyimak, melafalkan dan berbicara, membaca dan menulis. Bahwa langkah-langkah sistematik tersebut dilakukan secara berurutan. Penyajian secara berurutan tersebut merupakan keniscayaan metodik. Ini tentunya berbeda dengan penyajian materi.
Untuk terealisasikan urutan keterampilan berbahasa pada materi buku $D L A$, maka guru dituntut piawai menggunakan teknik-teknik mendemontrasikan materi tersebut. Karena urutan materi $D L A$ yang pertama adalah materi muthâla'ah, yang tergambar di otak tenaga pengajar adalah keterampilan membaca. Berbeda dengan urutan materi al-Arabiyyah li al-Nâsyi'ân yang menjadikan poros utamanya teks percakapan, maka teks tersebut sudah mengarahkan keterampilan berbicara lebih dahulu dari keterampilan membaca.

Pentahapan empat keterampilan berbahasa yang disajikan pertama adalah menyimak dan berbicara. Keterampilan membaca menempati posisi setelah keterampilan berbicara. Prioritas ini sesuai dengan dengan teori Driden dan Vos bahwa perolehan hasil belajar atau latihan melalui jalur ucapan (apa yang dikatakan dan dilakukan) mencapai prosentase $90 \%$. Sementara melalui bacaan hanya 10\%.( Dryden, Gorden dan Vos, Jeannette, 2000 : 100).

Proses pembelajaran akan lebih efektif ketika peserta didik diberi kesempatan untuk mempraktekan materi yang telah diterima. Belajar dengan melakukan lebih efektif daripada dengan mendengar atau melihat. Untuk itu, guru hendaknya lebih memberikan kesempatan kepada peserta didik untuk belajar dengan melakukan (larning by doing).

Teknik penyajian di atas, menggambarkan bahwa setiap sub bab dari materi merupakan satu kesatuan yang saling terkait. Contoh penyajian di atas dapat dijadikan patokan pada pelajaran yang lain dengan model penyajian tersebut. 


\section{Keterkaitan Keseluruhan Materi}

Satu materi dengan materi lainnya memiliki keterkaitan. Materi dalam suatu dars terdiri atas mufradât, mutâla'ah, muhâdatsah dan tata bahasa. Mutâla'ah merupakan bahan utama. Ketiga hal tersebut merujuk kepada mutâla'ah. Karenanya mutâla'ah menjadi poros utama. Dengan kata lain, pengembangan muhâdatsah diambil dari materi mutâla'ah. Demikian juga aspek tata bahasa. Sementara mufradât diambilkan dari materi mutâla'ah. Tentu yang diambil adalah kata-kata kunci yang disesuaikan dengan topik (mau$\left.\underline{d} \hat{u}^{\circ}\right)$ pembahasan.

Dengan demikian, kegiatan berbahasa dan pengembangan aspek pengetahuan bahasa, seperti struktur, kosakata, dan ejaan, tidak dipelajari secara lepas-lepas, terpotong-potong ataupun terkotak-kotak. Kegiatan pembelajaran aspek berbahasa dan pengembangan aspek pengetahuan bahasa dilakukan secara terpadu. Keterkaitan dalam penyajian materi utama dengan materi setelahnya mengambarkan keterpaduan seluruh komponen pada buku DLA. Keterkaitan tersebut seperti berikut ini: (1) Materi bacaan mengandung kosa kata yang disajikan dalam struktur kalimat yang diprogramkan. (2) Materi bercakap adalah pengembangan dari materi bacaan yang telah dikuasai siswa. (3) Materi tata bahasa adalah kesimpulan dari penerapan kaidah-kaidah pada materi bacaan dan percakapan. Pendekatan seperti ini dalam pengajaran kaidah bahasa disebut dengan pendekatan induktif. Yaitu pendekatan yang terlebih dahulu memberikan contoh-contoh secukupnya, setelah itu ditarik kesimpulan terhadap kaidah-kaidah bahasa yang terkandung di dalamnya.

\section{KESIMPULAN}

Berdasarkan uraian di atas, dapat disimpulkan bahwa Durûs Al-Lughah Al-'Arabiyyah bersesuaian dengan pendekatan Nazariyyah al-Wahdah. Yang dimaksud dengan kesesuian tersebut adalah kesesuaian dalam hal:

Pertama, materi disajikan secara sistematis yang terdiri atas lima pokok bahasan, yaitu: kosakata (mufradât), materi bacaan (mutâla'ah), kemudian materi percakapan (muhâadatsah), setelah itu diberikan tata bahasa (qawâid) dan menulis (ta'bir tahrîri dan imlâ'). Kelima komponen tersebut disajikan secara terpadu (Nazariyyah al-Wahdah/All In One System). Keterpaduan materi DLA berpusat kepada poros utama, yakni mutâla'ah. Dari materi mutâla'ah dikembangkan menjadi materi muhâdatsah, penerapan tata bahasa, dan latihan.

Kedua, materi-materi DLA dirancang dalam bentuk pembelajaran terpadu. Pelajaran kosakata misalnya, adalah pelajaran yang tidak diajarkan sebagai mata pelajaran yang berdiri sendiri melainkan terkait dengan pelajaran mutâla'ah, muhâdatsah, qawâ'id, dan tamrîn.

Ketiga, salah satu unsur penting dalam Nazariyyah al-Wahdah adalah gradasi, baik aspek struktur, tata bahasa dan maupun penyajian kata bantu dalam bentuk kalimat pertanyaan. 


\section{DAFTAR RUJUKAN}

Al-Khuliy, Muhammad Ali. 1989. Asâlibu Tadrîsil Lughatil Arabiyyah, Riyadh: Mathabi' alFarazdaq.

Effendy, Fuad. 2005. Metodologi Pengajaran Bahasa arab, Malang: Misykat.

Ibrâhim, Abdul 'Alîm. 1973. alMuwajjih al-Fany lil Mudarris alLughah al-Arabiyyah, Kairo; Dâr al-Ma'arif.

Ismail Shînî, Mahmud, dkk. 1983. Al'Arabiyyah Li al-Nasyi'în, Mamlakah al-'Arabiyyah al-Su'udiyyah.

Mansur, Moh. 1985. Materi Bahasa Arab I MKMP 3212/4 Modul 1, Direktorat Jenderal Pembinaan Kelembagaan Agama Islam dan Universitas Terbuka.

Muhammad Al-Qâsimi, Ali. 1979. Ittijahât Hadisah fi Ta'lîmil Arabiyah Lin Nathîgin bil Lughatil Ukhrâ, (Jami'atur Riyadh,).

Subana dan Sunarti, Strategi Belajar Mengajar Bahasa Indonesia; Berbagai Pendekatan, metode, Teknik dan Media Pelajaran, Bandung: Pustaka Setia, t.th.

Sumardi, Muljanto. 1975. Pengajaran Bahasa Asing. Sebuah Tujuan dari Metodologi, Jakarta: Bulan Bintang.

Syafruddin, Didin. 1995. "Mahmud Yunus wa 'Ittijahâtuhû fi Tajdîd Ta'lim al-Lughah al- 'Arabiyah bi Induni-siyâ", Studia Islamika, vol 2, no. 3, Jakarta; IAIN Syarif Hidayatullah

Tarigan, Henry Guntur. 1988. Berbicara Sebagai Suatu Keterampilan Ber-bahasa, Bandung:Angkasa

Yunus, Mahmud. 1983. Metodik Khusus Bahasa Arab (Bahasa Al-Qur'an), Jakarta: Hidakarya Agung.

------1980. Durûs al-Lughah al- 'Arabiyyah, Jakarta: Hidakarya Agung, , Jilid I, II, III, dan IV, Cet. 28

-1927 Durûs al-Lughah al-'Arabiyyah 'Ala at-Tarîqah al-Hadîsah, Jakarta: Hidakarya Agung, , Jilid I dan II.

----1982. Riwayat Hidup Prof. Dr. H. Mahmud Yunus, Jakarta; Hidakarya Agung 